\title{
A Comment on Ehud Ben Zvi's "Total Exile, Empty Land and the General Intellectual Discourse in Yehud"
}

\author{
NTozakhe Cezula (University of StellenbosCh)
}

\begin{abstract}
The Judeans of the pre-late-Persian period could not interpret the "empty land" myth other than in an inclusive manner. This approach is also reflected in Ezra-Nehemiah, according to Ehud Ben Zvi. This interpretation is clear from his social memory analysis of the pentateuchal, Deuteronomistic history and prophetic literature. The logic in his argument is so persuasive that it compels a review of one's stance on the exclusivity of Ezra-Nehemiah. After some engagement with Ezra-Nehemiah, this paper offers the argument that Ezra-Nehemiah is exclusive, and that the "empty land" myth is applied in an exclusive manner. Of great concern, however, is the fact that Ben Zvi's argument comes at a time when Africans are engaged in a quest for a biblical paradigm for a theology of reconstruction that is currently contemplated. Of more concern is that some scholars suggest Nehemiah as a paradigm for a theology of reconstruction in Africa, just as Moses and the Exodus, propound a theology of liberation. For historical reasons, this paper rejects Nehemiah as a biblical paradigm for a theology of reconstruction in Africa. This paper therefore engages with Ben Zvi's paper titled "Total Exile, Empty Land and the General Intellectual Discourse in Yehud" against this background.

KEYWORDS: De-Ideologisation; "Empty Land”; Myth; Ezra-Nehemiah; Land Dispute; Theology of Reconstruction.
\end{abstract}

\section{A INTRODUCTION}

Opening his paper, Ben Zvi says,

The ubiquitous concepts of "Empty Land" and "Total Exile" along with their associated metanarratives in the pre-late-Persian period required, and resulted in, the creation of social memory and forgetfulness that demands exploration, and an explanation for its success. ${ }^{1}$

* Submitted: 24/05/2017; peer-reviewed: 6/07/2017; accepted: 13/09/2017. Ntozakhe Cezula, "A Comment on Ehud Ben Zvi's 'Total Exile, Empty Land and the General Intellectual Discourse in Yehud'," OTE 30 no. 3 (2017): 592-608. DOI: https://doi.org/10.17159/2312-3621/2017/v30n3a4 
It is Ben Zvi's social memory theory that leads him to understand the theology of Ezra-Nehemiah as inclusive; this view motivated the arguments presented in the present article. I therefore respond to Ehud Ben Zvi's paper titled Total Exile, Empty Land and the General Intellectual Discourse in Yehud. This paper is also motivated by offering a response to his unfolding social memory analysis of the HB. I wish to re-examine my view that Ezra-Nehemiah applies the "empty land" idea that marginalises the remainees. Ultimately, however, I retain my stance. Four years after Ben Zvi's paper was published, Esias Meyer's paper titled Returning to an Empty Land: Revisiting my Old Argument about the Jubilee was published. In this paper, Meyer describes himself as one who "more than a decade ago ... set out as a committed contextual theologian to present another liberating reading of the Jubilee laws of Lev 25." ${ }^{2}$ Here, he denounces his previous view that the Jubilee was somehow related to the return of the elite and that they wanted their land back. Despite having changed his stance on the relationship between the Jubilee and the returning exiles, he still maintains that the "empty land" myth was related to the struggle for land between the exiles and the remainees, which relates to the second part of the argument. Meyer's stance that the "empty land" myth was related to the land struggle is significant for this paper, because it has implications for a theology of reconstruction in Africa. More significantly, this discussion takes place in a context where Jesse Mugambi $^{3}$ calls for Nehemiah to be a biblical paradigm for the reconstruction of Africa, and Nupanga Weanzana declaring that Ezra-Nehemiah is "the source for what African theologians have for some years been calling the theology of reconstruction." ${ }^{4}$ For me, thus, Ben Zvi's paper has implications for the discourse on reconstruction in Africa. This paper begins with a discussion on Ben Zvi's paper, then an exploration of Meyer's paper, while also discussing the discourse on a theology on reconstruction in Africa. Finally, a conclusion and an integration of the arguments are presented.

1 Ehud Ben-Zvi, "Total Exile, Empty Land and the General Intellectual Discourse," in The Concept of Exile in Ancient Israel and its Historical Contexts, ed. Ehud Ben-Zvi and Christoph Levin (Piscataway: Gorgias Press, 2010), 155.

2 Esias Meyer, "Returning to an Empty Land: Revisiting my Old Argument about Jubilee," OTE 27/2 (2014): 502.

3 Geoffrey W. Grogan, Psalms (Grand Rapids: William B. Eerdmans, 2008), 557. Jesse N. K. Mugambi, From Liberation to Reconstruction: African Christian Theology after the Cold War (Nairobi: East African Educational Publishers, 1995), 39; Jesse N. K. Mugambi, "Social Reconstruction of Africa: The Role of Churches," in The Church and Reconstruction of Africa: Theological Considerations (Nairobi: All Africa Conference of Churches, 1997), 1-25. Jesse N.K. Mugambi, "Foreword," in Theology of Reconstruction: Exploratory Essays, ed. Mary N. Getui and Emmanuel A. Obeng (Nairobi: Acton, 1999), i-iv; Jesse N. K. Mugambi, Christian Theology and Social Reconstruction (Nairobi: Acton, 2003), 172-173.

4 Nupanga Weanzana, "Ezra," in Africa Bible Commentary, ed. Tokunboh Adeyemo (Nairobi: World Alive Publishers, 2006), 531-42. 


\section{B EHUD BEN ZVI}

Ehud Ben Zvi argues that the concepts of "Total Exile" and "Empty Land" were a social success. This success cannot, however, be explained in terms of supposed exclusivism, discrimination and oppression imposed by exiles/returnees upon the remainees. It is rather an "inner logic of the shared central discourse that evolved through time and through social negotiation among local groups living a few hours' walk from each other in early Persian Yehud." 5 This process "contributed ... to social cohesion and to a construction of self-identity in Persian Yehud." Thus, the successful erasure of social memories of continuity among the remainees, and the replacement of these memories with memories that the remainees had, were counterfactual and cannot be explained by "an ideological, mystified representation of a historical oppression," 7 but by consensus among the different parties involved. According to Ben Zvi, this consensus was based on the understanding that if the exile was caused by the defilement of the land, a continued stay of the defilers on that land means that it was not purified, and thus guarantees no secured future for either the returnees or the remainees. This paper grapples with the logic of this argument.

However, I am also interested in Ben Zvi's perspective on Ezra-Nehemiah. In his dismissal of an "assumption of a central conflict between a few returnees supported by the Persian center (sic) and much larger local communities" ${ }^{8}$, he says:

... if one were to argue from Ezra 1-6, a text clearly later than the period covered here, one should note that it incorporates the entire population of Yehud into the community as returnees ${ }^{9}$... Ezra 10:29 constructs a later period, but it is worth noting that it suggests that membership into the community was open to those who identify with its ideology and socio-cultural (including cultic) norms ${ }^{10} \ldots[\mathrm{H}]$ aggai and Zechariah 1-8 (and Even Ezra-Nehemiah, for that matter) do not give the impression that severe, permanent conflicts arose between the small group of returnees and the majority of the population; in fact, the general image is one of unity. ${ }^{11}$

\footnotetext{
5 Ben-Zvi, "Total Exile," 167.

6 Ben-Zvi, "Total Exile," 167.

7 Ben-Zvi, "Total Exile," 167.

8 Ben-Zvi, Total Exile", 159.

9 Ben-Zvi, "Total Exile", 159.

10 Ben-Zvi, "Total Exile", 161, footnote 19.

11 To illustrate his consistency on this issue, this last quotation is from a different paper: Ehud Ben Zvi, "On Social Memory and Identity Formation in Late Persian Yehud," in Texts, Contexts and Readings in Postexilic Literature, ed. Louis C. Jonker (Tübingen: Mohr-Siebeck, 2011), 112-113.
} 
The impression is created here that the Ezra-Nehemiah returnees were willing to accept those who wanted to join them. However, this spirit is not discernible in Zerubbabel and the heads of fathers' houses in Ezra 4:1-6. ${ }^{12}$ Instead, Lester Grabbe convincingly notes that genealogies in Ezra 2:

inventory the population solely in terms of returnees; there is no hint that others were already living in the land or that they might also have rights. This chapter is firmly in the tradition of "the myth of the empty land." 13

Furthermore, a number of the foreigners in Ezra-Nehemiah were "traditional enemies of Israel and represent groups which had long since disappeared." ${ }^{14}$ I interpret this choice of extinct people as a distorted acknowledgment of remainees with whom they are in tension. Lastly, the Book of Chronicles that overtly advocates the "empty land" idea includes the twelve tribes, the southern kingdom and the northern kingdom when it refers to "all Israel" 15 However, Ezra-Nehemiah only refers to the exiles of Judah and Benjamin. ${ }^{16}$ Bringing these points together, I am not convinced that Ezra-Nehemiah made peace with the remainees.

In what seems to be an acknowledgment that in Ezra-Nehemiah something unbecoming is at stake, Ben Zvi stresses that his "study focuses on early Yehud, before the putative time of Ezra or Nehemiah and well before the time of the writing of Ezra 1-6 and Ezra-Nehemiah." ${ }^{\prime 7}$ This point is well taken. He

12 "1 Now the enemies of Judah and Benjamin heard that the [returned exiles] were building a temple for Yahweh the God of Israel. ${ }^{2}$ And they approached Zerubbabel and the heads of the [families], and they said to them, 'Let us build with you. Like you, we seek your God and have been sacrificing to him from the days of Esarhaddon the king of Assyria who brought us up here.' ${ }^{3}$ But Zerubbabel, Jeshua, and the rest of the heads of the [families] of Israel said to them, 'It is not for you but for us to build a house for our God. For we ourselves alone will build it for Yahweh the God of Israel, just as Cyrus the king of Persia has commanded us.' 4 Then the people of the land discouraged [the people of Judah] and made them afraid to build ${ }^{5}$ and bribed officials against them to frustrate their plan for all the days of Cyrus king of Persia until the reign of Darius king of Persia."

13 Lester L. Grabbe, Ezra-Nehemiah (London: Routledge, 1998), 11.

14 Grabbe, Ezra, 30.

15 Sara Japhet, The Ideology of the Book of Chronicles and its Place in Biblical Thought (Frankfurt: Peter Lang, 1997), 277-278; Ntozakhe Simon Cezula, Identity Formation and Community Solidarity: Second Temple Historiographies in Discourse with (South) African Theologies of Reconstruction, PhD Diss., Stellenbosch University, 2013, 174-175; Louis C. Jonker, 1 and 2 Chronicles (Grand Rapids: Baker Academic Press, 2013), 17.

16 Cezula, Identity Formation”, 131-138; Cf. Ezra 1:5; 4:1; 10:9; Neh 11:4, 36.

17 Ben Zvi, "Total Exile," 156. 
continues to state that he does not base any argument in his essay on the assumption that the world depicted in Ezra-Nehemiah reflects the historical circumstances of the shared discourse of literati in the pre-late Persian period. To reconstruct the latter, he prefers to use Pentateuchal, the (so-called) Deuteronomistic history and prophetic literature. ${ }^{18}$ I interpret this expression as meaning that Ezra-Nehemiah does not depict historical circumstances and thus should not be taken seriously. This notion is the core of my concern in the present paper. Before I explore this concern further, I offer a discussion of Esias Meyer's views.

\section{ESIAS MEYER}

The discussion of Esias Meyer in this paper reinforces my argument that the "empty land" myth was a strategy to marginalise remainees. In 2003, Meyer reasoned that the jubilee was a strategy for the returning exiles to reclaim their land from the remainees. He expresses this sentiment in Gerhard Wallis, saying:

For Wallis it was clear that the 50 year period was related to the period of exile. The Jubilee law of Lev 25 reflected something of the anxiety of the exiles about whether they would get their land back if they were to return after such a long time. The answer of the Jubilee law was "yes" they could...19

Ten years later, referring to this argument in an abstract, he states that on historical-critical grounds this argument about ch. 25 is rejected. ${ }^{20}$ He motivates that the fact that the $\mathrm{P}$ document was a post-exilic document and the H document was later than $\mathrm{P}$ made him realise that the Jubilee could not serve the purpose of the returning exiles. However, this does not mean that the Jubilee law was not written for the exiles to claim land, and Meyer also suggests that there was struggle for land between the returnees and the remainees and intuits that the exiles probably won the struggle. ${ }^{21}$ Meyer very much doubts Ben Zvi's argument that some kind of compromise was reached which was accepted by both sides. ${ }^{22} \mathrm{He}$ propounds that:

Still, even if the Jubilee law was not written with this purpose ${ }^{23}$ in mind, I do think that there must have been some struggle for land between the returnees and those who never left. ${ }^{24}$

According to Meyer, "land struggles are not easily forgotten, not voluntarily in any case." Using South Africa as an example, he states that: "... in the

18 Ben Zvi, "Total Exile," 156.

19 Meyer, "Returning," 504.

20 Meyer, "Returning," 502.

21 Meyer, "Returning," 516.

22 Meyer, "Returning," 513.

23 That is to justify the land claims of the returning exiles.

24 Meyer, "Returning," 513. 
year 2013 in South Africa we are very conscious of the 1913 Land Act and the unjust consequences it had for land ownership in this country." ${ }^{25}$ While Meyer disconnects the Jubilee from the returning exiles, Ndikho Mtshiselwa (2017), an African liberationist theologian, uses Meyer's paper on his new view as point of reference in his discussion. However, he uses Meyer's old view selectively and ignores the new view to support his [Mtshiselwa's] view that links the Jubilee and "empty land" myth to the returning exiles. When commenting on Meyer's new view, he says:

... Meyer has distanced himself from the argument he made a decade earlier that the close reading of Leviticus 25 and 26 alludes to the Babylonian exile returnees who sought to claim the so-called "empty land"... However, his argument appears inconclusive... Significantly, the rejection of the argument that Leviticus 25 and 26 refer to the élites about to return from exile who wanted their land - the socalled "empty land" - based on the post-exilic dating of Leviticus 25 is not convincing... The dating of certain layers of $\mathrm{P}$ and $\mathrm{H}$ to the exilic period would make Meyer's initial argument about the élite returnees who sought the so-called "empty land" appealing. ${ }^{26}$

These two scholars disagree on Lev 25 and 26 as alluding to the Babylonian exile returnees who sought to claim the so-called "empty land." For Mtshiselwa, the Jubilee was related to the exilic period. Meyer suggests that:

... about the second half of the fifth century, which is more than a century after Cyrus came to power in a period when other issues were to be addressed, a period in which the issues of the elite about to return from exile were no longer that relevant. ${ }^{27}$

However, these scholars both suggest that there was a land dispute in connection with the "empty land" myth between the exiles and the non-exiles, whether during the exilic period or later during the post-exilic period. Without joining their debate, besides Leviticus, the concept of "empty land" existed during the exilic period already. Hermann-Josef Stipp attests to a Jeremianic perspective of the "empty land" myth during the exilic period. ${ }^{28}$ While he does not associate the origin of this concept with a conflict between exiles and remainees, in general, the Book of Jeremiah alludes to a tension between the exiles and the

25 Meyer, "Returning," 513.

26 Vincent Ndikhokele Ndzondelelo Mtshiselwa, "Re-reading the Israelite Jubilee in Leviticus 25: 8-55 in the Context of Land Redistribution and Socio-Economic Justice in South Africa: An African Liberationist Perspective." PhD diss., UNISA, 2015, 291. 27 Meyer, "Returning," 513.

28 Hermann-Josef Stipp, "The Concept of the Empty Land in Jeremiah 37-43," in The Concept of Exile in Ancient Israel and its Historical Contexts, ed. Ehud Ben-Zvi and Christoph Levin (Piscataway: Gorgias Press, 2010). 
returnees. ${ }^{29}$ Carolyn Sharp refers to a " "pro-gola traditionists' resident in Babylon after 597 BCE" and "Judah-based traditionists" who purport two ideological perspectives in the prose of Jeremiah, and thus illustrating the tension between the two groups. ${ }^{30}$ Stipp concludes that this Jeremianic "empty land" myth:

... probably made a major contribution to forming a unique selfimage of the Babylonian exiles, and in the long run gave to the birth of the conviction, witnessed to in the books of Ezra and Nehemiah, that all postexilic Judeans were "sons of the golah" descended from the deportees. ${ }^{31}$

He does, however, not present a conclusive argument relating to this paper's and Ben Zvi's contestation that the concept under discussion relates to a marginalising theology. The acknowledgement of a land dispute by Meyer, and of course Mtshiselwa, reinforces my argument that Ben Zvi's view that there was social cohesion is not convincing. As indicated above, one cannot ignore the tension discernible in the book of Ezra-Nehemiah, so that one can explore the possibility that this book can contribute productively to the process of reconstruction in Africa. A reading that does not reveal the land struggle in Ezra-Nehemiah, in Elelwani B. Farisani's words:

... may be counterproductive, in that instead of supporting and advancing the cause of the poor and marginalised, such a reading may further marginalise the poor by further enslaving them with the "revealed word of God." 32

Such a state of affairs cannot serve reconstruction in Africa in a positive manner. This is why I engage with Ben Zvi's paper, especially in terms of the "empty land" myth. Ben Zvi's social memory analysis and thus his understanding of the "empty land" myth exonerates Ezra-Nehemiah from a political plot against the poor who remained behind. I now outline the discourse on reconstruction from my point of view.

\section{RECONSTRUCTION IN AFRICA}

Jesse Mugambi is widely recognised as the initiator of this discourse. He argues that liberation theology has played its role, but now that we are beyond colonial and apartheid times, we need a theology of reconstruction; a biblical paradigm

29 This paper, however, does find a depiction of animosity between the exiles and the remainees in Jeremiah.

30 Carolyn J. Sharp, Prophecy and Ideology in Jeremiah: Struggles for Authority in the Deutero-Jeremianic Prose (New York: T\&T Clark, 2003), 158.

31 Stipp, "Concept," 152-154.

32 Elelwani B. Farisani, "The Use of Ezra-Nehemiah in a Quest for a Theology of Renewal, Transformation, and Reconstruction in the (South) African Context" (PhD diss., University of KwaZulu-Natal, 2002), 141. 
that is like Moses and the Exodus to liberation theology. ${ }^{33}$ Many have responded in their unique ways to this quest. ${ }^{34}$ Important for this particular discussion is Mugambi's suggestion of Nehemiah as a biblical paradigm for reconstruction in Africa. In a well-articulated dissertation, Elelwani Farisani dismisses Nehemiah as a biblical paradigm for reconstruction in Africa. He bases his argument on the discriminatory tendencies in the Book of Ezra-Nehemiah. Unfortunately, he proposes nothing in the place of this paradigm. ${ }^{35}$ Ntozakhe Cezula supports Farisani's views and proposes Chronicles as a biblical paradigm for reconstruction in Africa. Cezula further argues that Ezra-Nehemiah has been used by both Nazi and apartheid ideologues to justify their ideologies, and that in the future, others might also use this book to justify discriminatory ideologies. ${ }^{36}$ After Africa's experiences of discrimination, I argue that Ezra-Nehemiah cannot be regarded as a biblical paradigm for reconstruction in Africa. Given that there are proponents of Nehemiah as a biblical paradigm for reconstruction in Africa, I am concerned that Ben Zvi's paper portrays Ezra-Nehemiah as inclusive. I accept Ben Zvi's articulation of the "empty land" myth because this view supports the notion that Chronicles illustrates that kind of spirit as uniting Israel. ${ }^{37}$ However, I am concerned with the portrayal of Ezra-Nehemiah as inclusive, because I am convinced that the book insinuates the dehumanisation of some groups in the name of God. Apartheid has done this before and it should never, ever happen again. As a black South African, I am of the opinion that the exclusive ethnic

33 Mugambi, Jesse N. K. From Liberation to Reconstruction: African Christian Theology after the Cold War. Nairobi: East African Educational Publishers, 1995; "Social Reconstruction of Africa: The Role of Churches." Pages 1-25 in The Church and Reconstruction of Africa: Theological Considerations. Nairobi: All Africa Conference of Churches, 1997; "Foreword." Pages i-iv in Theology of Reconstruction: Exploratory Essays. Edited by Mary N. Getui and Emmanuel A. Obeng. Nairobi: Acton, 1999; Christian Theology and Social Reconstruction. Nairobi: Acton, 2003.

34 Charles Villa-Vicencio, A Theology of Reconstruction: Nation-building and Human Rights (Cambridge: Cambridge University Press, 1992); André Karamaga, "A Theology of Reconstruction," in Democracy and Development in Africa: The Role of the Churches, ed. Jesse N. K. Mugambi (Nairobi: All Africa Conference of Churches, 1997), 190-191; Farisani, "Use of Ezra-Nehemiah"; Jean-Claude Loba-Mkole, "Bible Translation and Reconstruction Hermeneutics," in Theologies of Liberation and Reconstruction, ed. Isaac M. T. Mwase and Eunice K. Kamaara (Nairobi: Acton Publishers, 2012), 146-170, and others. There are many responses to this quest that have not been included. They are recognised but for argument's sake have been subsumed into the mentioned ones.

35 Farisani, "Use of Ezra-Nehemiah."

36 Ntozakhe S. Cezula, "De-Ideologizing Ezra-Nehemiah: Challenging Discriminatory Ideologies," in Restorative Readings: The Old Testament, Ethics, and Human Dignity, ed. L. Juliana Claassens and Bruce Birch (Eugen, OR: Wipf \& Stock, 2015), 117138.

37 Cezula, "De-Ideologizing," 117-138. 
theology in Ezra-Nehemiah should not be downplayed. These remarks necessitate a discussion on ways to de-ideologise Ezra-Nehemiah.

\section{E DE-IDEOLOGISING EZRA-NEHEMIAH}

It might be helpful to highlight a number of different perspectives on EzraNehemiah. Given that I regard Ezra-Nehemiah as one of the Chronicler's sources, I also regard this source as earlier than Chronicles. ${ }^{38}$ Ben Zvi, on the other hand, dates Chronicles towards the end of the Persian era and describes Ezra-Nehemiah as "a post-Persian-period book that purports to describe some events of the period." ${ }^{39}$ His analysis is historiographical ${ }^{40}$ and therefore social memory-related. My mode of inquiry, on the other hand, is literary-ideological. At this juncture, I concur with Ben Zvi when he says:

By necessity all lenses (i.e. methodological approaches) allow us, as scholars, to see certain things, but also obscure others. In fact, not only does each methodological approach help us to "notice" different sets of data and their significance, but each methodological approach raises different research questions. ${ }^{41}$

Different analytical methods prompt specific questions, and thus different answers may arise. I raise these differences because one's stance on the above issues influences one's view of the extent, authorship, compositional theory, historical reconstructions and theologies of these texts. In my case, there is a difference on the theology of Ezra-Nehemiah as far as the "empty land" myth is concerned.

In the quest for a theology of reconstruction and its paradigm in Africa, the notion of ideology in the Bible is significant. Accordingly, Elelwani Farisani argues that:

$\ldots$ in order to effectively use any text in the reconstruction process in Africa, without it further oppressing and silencing the already

38 Cf. Jonker, 1 \& 2 Chronicles, 11, 311. See also 2 Chr 36:21-22 and Ezra 1:1-3.

39 Ben-Zvi, "On Social Memory," 104, fn. 26. This paper finds merit in James T. Sparks' question whether the Chronicler encouraged loyalty to Persia. If so, which is very likely, it means the Persian Empire still existed. If Persia had already fallen in the hands of the Greeks it would be unlikely that the Chronicler would still be encouraging loyalty to the Persians. Consequently, a date prior to 330 would be in view for the production of Chronicles. See James T. Sparks, The Chronicler's Genealogies: Towards an understanding of 1 Chronicles 1-9 (Atlanta: Society of Biblical Literature, 2008), 366-367.

40 I use historiographical instead of historical to evince adaptation.

41 Ehud Ben-Zvi, "Chronicles and Social Memory," ST 71 (2017): 22, doi: 10.1080 /0039338X.2017.1308718. 
silenced and marginalized poor, the text's ideology has to be subjected to a rigorous sociological analysis, so as to de-ideologise it. ${ }^{42}$

To de-ideologise is to reveal the dominant ideology in a text. In the case of Ezra-Nehemiah, it is an exclusive ethnic ideology that discriminates against a section of the community. The idea of de-ideologising is justified by Gale Yee when she says:

The Bible was not written to be an object of aesthetic beauty or contemplation, but as a persuasive force forming opinion, making judgments, and exerting change. It was a form of power acting upon the world. $^{43}$

Earlier, this idea has been articulately and intelligently expressed by Itumeleng Mosala when he argued that biblical "texts are productions (sic), or 'signifying practices,' that reconstitute in very specific ways the realities of the material conditions of which they are products." 44 Apart from being products of their material conditions, these texts are also sites of struggle of their material conditions. ${ }^{45}$ Mosala's argument is brought to a climax in Gerrie Snyman's paraphrasing when he says:

To him, not everything in the Bible is on the side of human rights or of the oppressed and marginalised people. Moreover, oppressive texts cannot be totally tamed or subverted into liberating texts. Failing to recognise that, would mean that oppressors and exploiters in the text become comrades in arms. ${ }^{46}$

This paper's argument is that Ben Zvi's assertion that the "empty land" myth in Ezra-Nehemiah is inclusive is an effort to tame an oppressive text and thus subvert it into a liberating text. ${ }^{47}$ Such an argument can promote the notion of Nehemiah being a candidate for a paradigm of reconstruction in Africa. This is a concern for this paper. This concern is clearly expressed by Gerrie Snyman when he comments on a sermon he listened to. In this sermon, "the congregation is called to be obedient to God no matter the cost in contrast to the world that

42 Farisani, "Use of Ezra-Nehemiah," 297.

43 Gale A. Yee, "The Author/Text/Reader and Power: Suggestions for a Critical Framework for Biblical Studies," in Social Location and Biblical Interpretation in the United States, vol. 1 of Reading from this Place, ed. Fernando F. Segovia and Mary A. Tolbert (Minneapolis: Fortress Press, 1995), 116.

44 Itumeleng J. Mosala, Biblical Hermeneutics and Black Theology in South Africa (Grand Rapids: William B. Eerdmans, 1989), 7.

45 Mosala, Biblical Hermeneutics, 20.

46 Gerrie Snyman, "Collective Memory and Coloniality of Being as a Hermeneutical Framework: A Partialised Reading of Ezra-Nehemiah,” OTE 20/1 (2007): 72.

47 Besides the division between exiles and remainees, the xenophobic attitudes in this book cannot serve South Africa best which at the moment demonstrates xenophobic tendencies, for example. 
remains disobedient." In the sermon, the preacher instilled fear in the congregation by invoking God's judgement in the last days. Snyman "was struck by the ease with which perpetrators were turned into martyrs for doing the will of God"48 and thus notes that:

My main problem with the sermon has been that the failure to take the victims' situation seriously could enable the reader to commit cruel acts in the name of God. A hermeneutic that remains insensitive to oppressive biblical texts, disempowers the reader to construct a new way of being after apartheid... The assumed benevolence masks those texts that are oppressive and its cruelty hides behind the will of God. And doing the will of God is what about every Christian intends to do. It makes one feel good and not evil. I believe apartheid shattered that conviction and we need now a critical sensibility to recognise oppressiveness in biblical texts.... After apartheid, I am left with some serious questions about the story's moral vision, even when God is drawn into the argument. ${ }^{49}$

Furthermore, Musa Dube decries the use of the Bible to oppress other people. She argues that:

... classical texts such as the Bible... have inspired and participated in different historical processes of imperialism ${ }^{50} \ldots$ Many biblical narratives are imperializing texts, through their use in history and through the power relations they propound. ${ }^{51}$

I argue that Ezra-Nehemiah has inspired different historical processes of oppression. This narrative did so through its use in history by discriminatory ideologues and through the power relations that the text itself propounds. In two previous papers ${ }^{52}$, I related defences of discriminating ideologies by using EzraNehemiah. I am obliged to repeat these here. Julius Streicher ${ }^{53}$ and Prof Dr E. P. Groenewald $^{54}$ are quoted below respectively:

\footnotetext{
48 Snyman, "Collective Memory," 57.

49 Snyman, "Collective Memory," 79.

50 Musa Dube, "Reading for Decolonization (John 4:1-22)," Semeia 75 (2001): 42.

51 Dube, "Reading," 56.

52 Cezula, Ntozakhe S. "De-Ideologizing Ezra-Nehemiah: Challenging Discriminatory Ideologies." Pages 117-138 in Restorative Readings: The Old Testament, Ethics, and Human Dignity. Edited by L. Juliana Claassens and Bruce Birch. Eugen, OR: Wipf \& Stock, 2015; Cezula, NS, "The Concept of 'the Holy Seed' as a Coping Strategy in Ezra-Nehemiah," in Acta Theologica, forthcoming.

53 Julius Streicher had been a publisher, editor and writer for the German newspaper Der Stürmer and Nazi activist. He was questioned in relation with the Nuremberg Laws of 1935 on 26 April 1946.

54 Prof Dr E. P. Groenewald was professor of NT exegesis and theology at the University of Pretoria.
} 
(Julius Streicher)... the Jews should serve as an example to every race... and that, Gentlemen, is of tremendous importance in judging the Nuremberg Laws. These laws of the Jews were taken as a model for these laws. When, after centuries, the Jewish lawgiver Ezra discovered that notwithstanding many Jews had married non-Jewish women, these marriages were dissolved. That was the beginning of Jewry which, because it introduced these racial laws, has survived throughout the centuries, while all other races and civilizations have perished. ${ }^{55}$

(EP Groenewald) This truth is confirmed in the history of Christianity. The Lord who willed the segregation of the nations, abundantly blessed the nations which respected His stipulation and also used them as a blessing to humanity in general ... To Israel the Lord instructs that there should be no mixing with foreign nations ... The Scripture views it generally as a deviation from the will of God when Israel allows that her sons and daughters marry with other nations. Such marriages let national differences grow faint and lead to undermining of the mother tongue. The result is a generation that does not honour or even know its own language, customs, religion and also nationality. So writes Nehemiah $(13: 23) .{ }^{56}$

The above quotations relate to Snyman's remark that "Ezra and Nehemiah's handling of the foreign women render their reconstruction projects questionable." ${ }^{57}$ I argue that for a theology of reconstruction in Africa that avoids "further oppressing and silencing the already silenced and marginalized poor,"58 the exclusivity of the "empty land" myth in Ezra-Nehemiah should be exposed.

I also relate to Hugh Williamson ${ }^{59}$ and John A. Thompson ${ }^{60}$ when they state that "there is evidence of considerable disagreement at the time of Chronicles concerning how 'open' or 'exclusive' a stance should be taken towards those outside the confines of the group centred on Jerusalem."61 Although these

55 International Military Tribunal, One Hundred and Eleventh Day to the One Hundred and Nineteenth Day, vol. 12 of Nuremberg Trial Proceedings (Nuremberg: International Military Tribunal, 1947), 315, online: http://www.loc.gov/rr/frd/Military Law/pdf/NT_Vol-XII.pdf.

56 This is my own translation of the original expression in Afrikaans. Evert P. Groenewald, "Apartheid en Voogdyskap in die Lig van die Heilige Skrif," in Regverdige Rasse-Apartheid, ed. G. Cronjé, Wm. Nicol and Evert P. Groenewald (Stellenbosch: Christen-Studentevereniging Boekhandel, 1947), 52-53.

57 Snyman, "Collective Memory," 79.

58 Farisani, "Use of Ezra-Nehemiah," 297.

59 Hugh G. M. Williamson, 1 and 2 Chronicles, NCB (London: Marshall Morgan \& Scott, 1982), 24.

60 John A. Thompson, 1 \& 2 Chronicles, NAC 9 (Nashville: Broadman \& Holman, 1994), 33.

61 Williamson, 1 and 2 Chronicles, 24; Thompson, 1 \& 2 Chronicles, 33. 
authors do not provide this evidence, my persuasion is based on the different ethnic theologies discernible in Ezra-Nehemiah and Chronicles. ${ }^{62}$ At this point, I consider a scenario portrayed in $2 \mathrm{Kgs} 25: 12$, Jer 39:10 and Jer 52:12, namely that the Babylonians exiled some and left some of the poorest of the land. They gave vineyards and fields to the poor who did not have land to be vinedressers and plowmen. In light of what these texts suggest, Louis Jonker expresses a highly likely scenario when he says:

The returning exiles had to integrate into a society of Israelites and Judahites who existed alongside one another and who did not experience the exile. One may assume that tension between the "remainees" and the "returnees" would have developed in this period. ${ }^{63}$

This supposed context reinforces my view of the reconciling spirit represented by Chronicles vis-à-vis the alienating perspective represented by EzraNehemiah. Ben Zvi's understanding of the "empty land" myth is also accepted in this framework. The spirit of this view is encapsulated by Jonker who argues that $2 \mathrm{Chr} 36$ preached that:

... the old divisions of the past have been restored by the Sabbath rest of the Exile, and that a New Israel emerged who had the opportunity of a fresh beginning under Persian rule. ${ }^{64}$

Given the different ideological positions found in the Persian period, I argue that Ezra-Nehemiah can contribute towards a theology of reconstruction in Africa - but only when de-ideologised. The book can warn us about what to avoid in the process of reconstructing the African continent. Its use of the "empty land" myth can help us understand the notion of the "empty land" myth in South Africa. It is clear that the "empty land" myth is an old one that can be traced back to biblical times. Referring to the use of the "empty land" myth in South Africa, Richard W. Johnson propounds that South Africa "widely shared notions current right from the beginning of the colonial era" and that "apartheid historians merely turned these crude notions of cultural anthropology into a doctrine..."65 Chronicles can also help us analyse the use of the "empty land" myth in South Africa.

\section{F CONCLUSION}

In this paper, I grappled with Ehud Ben Zvi's conceptualisation of the "empty land" myth during the post-Babylonian exilic era. According to him, the concepts

62 Cf. Cezula, "Identity Formation", 118-193.

63 Jonker, "1 and 2 Chronicles," 18.

64 Louis C. Jonker, "The Exile as Sabbath Rest: The Chronicler's Interpretation of the Exile," OTE 20/3 (2007): 715.

65 Richard W. Johnson, South Africa: The First Man, the Last Nation (Cape Town: Jonathan Ball Publishers, 2004), 1. 
of "total exile" and "empty land" cannot be explained in terms of supposed exclusivism, discrimination and oppression imposed by exiles/returnees upon the remainees. It is rather an:

... inner logic of the shared central discourse that evolved through time and through social negotiation among local groups living a few hours walk from each other in early Persian Yehud. ${ }^{66}$

This process "contributed ... to social cohesion and to a construction of selfidentity in Persian Yehud." ${ }^{\circ 7}$ Using social memory analysis, "historical facts" evinced by this analysis convinced him to this stance. Ben Zvi includes EzraNehemiah in this inclusivity. This is my point of contention in this article. $\mathrm{He}$ argues that even Ezra-Nehemiah stood for the unity of all Judeans; the returnees and the remainees. The logic in Ben Zvi's argument is so persuasive that it challenged me to re-examine my view that Ezra-Nehemiah applies the "empty land" idea to marginalise the remainees. However, the literary-ideological analysis I use, convinced me that Ezra-Nehemiah suggests an exclusive ethnic theology/ideology directed even to fellow Judeans who did not go to exile. This argument is underscored by two South African OT theologians, namely Esias Meyer and Ndikho Mtshiselwa. In their reading of Lev 25 and 26, these theologians disagree on the date of this text. Meyer dates it to more than a century after Cyrus came to power. In Meyer's view, therefore, this is a period in which the issues of the elite about to return from exile were no longer relevant. The Jubilee could thus not have been meant to justify the land claims of the returning exiles. Mtshiselwa, on the other hand, dates these chapters in the exilic period. According to him, the Jubilee was meant to justify the land claims of the returning exiles. This is significant for my argument, because this view reinforces the idea of the agenda of the exiles to marginalise the remainees which is also discernible in Ezra-Nehemiah. Despite the differences in their arguments, both these authors acknowledge that there was a struggle for land between the exiles and the remainees. I support this notion. I also heed the fact that both Meyer and Mtshiselwa ${ }^{68}$ deal with periods different from the period Ben Zvi claims to be dealing with in Total Exile, Empty Land and the General Intellectual Discourse in Yehud. Meyer deals with a period of more than a century since the initial return. He takes his cue from Juha Pakkala's article, which engages with the Ezra narrative in the same volume as Ben Zvi's article. In other words, he deals with the Ezra-Nehemiah period. Ben Zvi argues that his article "focuses on early Yehud, before the putative time of Ezra or Nehemiah and well before the time of the writing of Ezra 1-6 and Ezra-Nehemiah." He further explains that he does not:

66 Ben-Zvi, "Total Exile," 167.

67 Ben-Zvi, "Total Exile," 167.

68 He also deals with a different book from the one this article is concerned with. 
... base any argument in this essay on the assumption that the world depicted in Ezra-Nehemiah reflects the historical circumstances of the shared discourse of literati in the pre-late Persian period. ${ }^{69}$

Mtshiselwa, on the other hand, deals with the exilic period. Thus, both my supporting articles deal with periods different from the period Ben Zvi claims to address. I posit that there was never a period of social cohesion between the exile and the time of Ezra-Nehemiah. Meyer refers to an early P document acknowledging the presence of people to share the land with the returning exiles and thus depicting a land struggle, as well as a later $\mathrm{H}$ document that depicts an "empty land" but that still supposes a land struggle. If one takes into consideration the tensions depicted in the books of Jeremiah and Ezekiel as well as Meyer's argument, it seems as if there was never a period of social cohesion between the exile and the time of Ezra-Nehemiah - as Williamson and Thompson seem to suggest. Very significant for my argument is that Ben Zvi argues that:

$\ldots$ if one were to argue from Ezra 1-6, a text clearly later than the period covered here, one should note that it incorporates the entire population of Yehud into the community as returnees. ${ }^{70}$

This statement suggests that the remainees were accepted as part of the Yehud community. I disagree and argue that it excluded the remainees. Ben Zvi's argument persuaded a number of people. This is a concern for me, because from some quarters in Africa there are calls for Nehemiah to be a biblical paradigm for the reconstruction of Africa. I therefore posit that Ben Zvi's paper has implications for the discourse on a theology of reconstruction in Africa. For this reason, I argue that the exclusive ethnic theology/ideology present in Ezra-Nehemiah should not be concealed, but must be exposed. For Ezra-Nehemiah to be beneficial for a theology of reconstruction in Africa it needs to be de-ideologised. One positive contribution Ezra-Nehemiah can make to the discourse of a theology of reconstruction in Africa is to warn Africans against discriminative theologies/ideologies.

\section{BIBLIOGRAPHY}

Ben-Zvi, Ehud. "Total Exile, Empty Land and the General Intellectual Discourse." Pages 155-168 in The Concept of Exile in Ancient Israel and its Historical Contexts. Edited by Ehud Ben-Zvi and Christoph Levin. Piscataway, Gorgias Press, 2010.

. "On Social Memory and Identity Formation in Late Persian Yehud." Pages 95-148 in Texts, Contexts and Readings in Postexilic Literature.

Edited by Louis C. Jonker. Tübingen: Mohr-Siebeck, 2011.

."Chronicles and Social Memory." ST 71 (2017): 1-22. Doi: 10.1080 /0039338X.2017.1308718.

69 Ben-Zvi, "Total Exile," 156, footnote 3.

70 Ben-Zvi, "Total Exile," 161. 
Cezula, “A Comment on Ehud Ben Zvi’s,” OTE 30/3 (2017): 592-608

Cezula, Ntozakhe S. Ntozakhe Simon Cezula, "Identity Formation and Community Solidarity: Second Temple Historiographies in Discourse with (South) African Theologies of Reconstruction", PhD Diss., Stellenbosch University, 2013. ."De-Ideologizing Ezra-Nehemiah: Challenging Discriminatory Ideologies." Pages 117-138 in Restorative Readings: The Old Testament, Ethics, and Human Dignity. Edited by L. Juliana Claassens and Bruce Birch. Eugen, OR: Wipf \& Stock, 2015. ."The Concept of 'the Holy Seed' as a Coping Strategy in EzraNehemiah." Forthcoming in Acta Theologica.

Dube, Musa. "Reading for Decolonization (John 4:1-22)." Semeia 75 (2001): 37-59.

Farisani, Elelwani B. "The Use of Ezra-Nehemiah in a Quest for a Theology of Renewal, Transformation, and Reconstruction in the (South) African Context." PhD diss., University of KwaZulu-Natal, 2002.

Grabbe, Lester L. Ezra-Nehemiah. London: Routledge, 1998.

Groenewald, Evert P. "Apartheid en Voogdyskap in die Lig van die Heilige Skrif." Pages 40-67 in Regverdige Rasse-Apartheid. Edited by G. Cronjé, Wm. Nicol, and Evert P. Groenewald. Stellenbosch: ChristenStudentevereniging Boekhandel, 1947.

Grogan, Geoffrey W. Psalms. Grand Rapids: William B. Eerdmans, 2008. Japhet, Sara. The Ideology of the Book of Chronicles and its Place in Biblical Thought. Frankfurt: Peter Lang, 1997.

Johnson, Richard W. South Africa: The First Man, the Last Nation. Cape Town: Jonathan Ball Publishers, 2004.

Jonker, Louis C. "The Exile as Sabbath Rest: The Chronicler's Interpretation of the Exile." OTE 20/3 (2007): 703-719. . 1 and 2 Chronicles. Grand Rapids: Baker Academic Press, 2013.

Karamaga, André. "A Theology of Reconstruction.” Pages 190-191 in Democracy and Development in Africa: The Role of the Churches. Edited by Jesse N. K. Mugambi. Nairobi: All Africa Conference of Churches, 1997.

Loba-Mkole, Jean-Claude. "Bible Translation and Reconstruction Hermeneutics." Pages 146-170 in Theologies of Liberation and Reconstruction. Edited by Isaac M. T. Mwase and Eunice K. Kamaara. Nairobi: Acton Publishers, 2012.

Meyer, Esias. "Returning to an Empty Land: Revisiting my Old Argument about Jubilee." OTE 27/2 (2014): 502-519.

Mosala, Itumeleng J. Biblical Hermeneutics and Black Theology in South Africa. Grand Rapids: William B. Eerdmans, 1989.

Mtshiselwa, Vincent Ndikhokele Ndzondelelo. "Re-reading the Israelite Jubilee in Leviticus 25: 8-55 in the Context of Land Redistribution and SocioEconomic Justice in South Africa: An African Liberationist Perspective." PhD diss., UNISA, 2015. 
Mugambi, Jesse N. K. From Liberation to Reconstruction: African Christian Theology after the Cold War. Nairobi: East African Educational Publishers, 1995. " "Social Reconstruction of Africa: The Role of Churches." Pages 1-25 in The Church and Reconstruction of Africa: Theological Considerations. Nairobi: All Africa Conference of Churches, 1997. . "Foreword." Pages i-iv in Theology of Reconstruction: Exploratory Essays. Edited by Mary N. Getui and Emmanuel A. Obeng. Nairobi: Acton, 1999. Christian Theology and Social Reconstruction. Nairobi: Acton, 2003.

International Military Tribunal. One Hundred and Eleventh Day to the One Hundred and Nineteenth Day. Vol. 12 of Nuremberg Trial Proceedings. Nuremberg: International Military Tribunal, 1947. Online: http://www. loc.gov/rr/frd /Military_Law/pdf/NT_Vol-XII.pdf.

Sharp, Carolyn J. Prophecy and Ideology in Jeremiah: Struggles for Authority in the Deutero-Jeremianic Prose. New York: T\&T Clark, 2003.

Snyman, Gerrie. "Collective Memory and Coloniality of Being as a Hermeneutical Framework: A Partialised Reading of Ezra-Nehemiah." OTE 20/1 (2007): 53-83.

Sparks, James T. The Chronicler's Genealogies: Towards an Understanding of 1 Chronicles 1-9. Atlanta: Society of Biblical Literature, 2008.

Stipp, Hermann-Josef. "The Concept of the Empty Land in Jeremiah 37-43." Pages 103-154 in The Concept of Exile in Ancient Israel and its Historical Contexts. Edited by Ehud Ben-Zvi and Christoph Levin. Piscataway: Gorgias Press, 2010.

Thompson, John A. $1 \& 2$ Chronicles. NAC 9. Nashville: Broadman \& Holman, 1994.

Villa-Vicencio, Charles. A Theology of Reconstruction: Nation-building and Human Rights. Cambridge: Cambridge University Press, 1992.

Weanzana, Nupanga. "Ezra." Pages 531-42 in Africa Bible Commentary. Edited by Tokunboh Adeyemo. Nairobi: World Alive Publishers, 2006. Williamson, Hugh G. M. 1 and 2 Chronicles. NCB. London: Marshall Morgan \& Scott, 1982.

Yee, Gale A. "The Author/Text/Reader and Power: Suggestions for a Critical Framework for Biblical Studies.” Pages 109-118 in Social Location and Biblical Interpretation in the United States. Vol. 1 of Reading from this Place. Edited by Fernando F. Segovia and Mary A. Tolbert. Minneapolis: Fortress Press, 1995.

Dr Ntozakhe Cezula, Department of Old and New Testament, University of Stellenbosch.Email: cezulans@sun.ac.za. 